\title{
プローブデータに基づく推定経路交通量への観測誤差の影響分析と推定経路交通量の更新手法*
}

\section{Influence of Measurement Errors of Input Data on Path Flow Estimations from Probe Vehicle Information} and Modification of Estimated Path Flows*

\author{
堀場庸介**・松本幸正 $* * *$ 松井寛 $* * * * \cdot$ 高橋政稔 $* * * * *$ \\ By Yosuke HORIBA** • Yukimasa MATSUMOTO*** $\cdot$ Hiroshi MATSUI ${ }^{* * * *} \cdot$ Masami TAKAHASHI
}

\section{1.はじめに}

経路交通量は, 断面交通量やOD交通量では把握できな い, 車両の走行経路を捉えることができ, 情報提供や交 通制御などの交通運用施策を実施する上で, 重要な指標 の 1 つとなる. 特に, 代替経路が存在する複数経路ネッ トワークを効率的に運用するためには, 経路交通量の把 握は不可欠であり, 得られた経路情報をもとに交通量の 空間的な平淮化を図ることが求められる. しかしながら, 経路交通量を直接観測することは未だ容易ではなく, 経 路交通量を推定する手法の確立が急務である.

一方, 車両感知器では道路上の地点交通量を直接観測 することが可能なことから, 観測リンク交通量からOD 交通量を推定する問題は，これまでに多くの研究者を惹 きつけてきた.リンク交通量とOD交通量の関係を記述す るには, OD交通量を経路交通量に細分する必要があり, 一般に, OD交通量に経路利用率を乗じることによって経 路交通量を表現する. この際, 経路利用率の与え方によ ってOD交通量の推定モデルは大別される.1つは経路利 用率を固定值として与えるモデル(1)2)であり，1つは交通 混雑に応じて変化する值として与えるモデル3), 4), 5)であ る. 経路交通量を観測リンク交通量に基づいて推定する 方法として, Bell $ら^{6}$ は経路選択率を確率均衡配分から与 えられるとしてモデルを定式化し, Matsumoto うらは経路 選択率をDial配分により得られるとして動的な経路交通 量の推定モデルを提案している. しかしながら, 以上の モデルは, 現況の道路状況におけるドライバーの経路選 択行動を反映したモデルとはなっていない.

最近では, ITSの普及により, 詳細な交通データの収 集も可能となってきた. 中でも, プローブカー情報はド ライバーの経路選択行動のデータが収集可能であり, 我

*キーワーズ : プローブ, 経路交通量, 観測誤差

**学生員, 名城大学大学院理工学研究科

***正員, 博(工), 名城大学理工学部建設システム工学科

（名古屋市天白区塩釜口1-501， TEL:052-832-1151，

E-mail:matumoto@civil.meijo-u.ac.jp)

****フェロー, 工博, 名城大学理工学部建設システム工学科

*****正員, 博 (工), 名城大学理工学部環境創造学科
が国でも既に実験が始まっており，近い将来の普及・実 用化が見込まれる. 同様に, VICSやDSRCなどを利用し た車両の走行情報の取得も可能となり, さらに今後, 様々 な形でドライバーの経路選択行動に関する情報の入手が 可能となってくると考えられる. そのような中, 北村ら ${ }^{8)}$ は, 幹線の交通状況が細街路通過交通に及ぼす影響を見 るため, 現地調査より取得した幹線, 細街路の速度デー タとプローブカーの速度データに基づく分析を行い, プ ローブカーデータが調査の速度データを補完・代替する ために有効であることを示している. また, プローブデ 一タにより，現地調査では収集が困難である細街路中の 車両の挙動や, 細街路通過前後の経路について詳細なデ 一タを得ることが可能となることが示されている. 三輪 ら゙は, プローブデータを用いた予測所要時間の更新方法 を提案し，三輪ら ${ }^{10}$ はプローブカーデータを用いた動的 な経路選択モデルを提案している.このように，実際の 道路状況を的確に表す情報源としてのプローブデータの 利用は着々と進んできている.

OD交通量を推定する際の経路選択率としてプローブデ 一タを利用した研究として, 小根山ら ${ }^{11)}$ は交通流シミュ レーション上で, プローブデータと車両感知器のデータ を用いて時間帯別OD交通量の推定手法を提案している. 三谷ら ${ }^{12}$ は，プローブパーソンデータを経路データとし て利用し,動的OD交通量をシミュレータによって推定し ている. しかしながらこれらのモデルは, シミュレーシ ヨンによりOD交通量が推定されており,その推定経路交 通量の特性はシミュレーションに大きく依存しており， 解析的に明らかにすることも難しい。

観測交通量に基づいて経路交通量を推定するは，一般 に, 事前OD交通量, 経路選択率, 観測リンク交通量など が入力データとして必要であるが, 実際には, これらの データ間には, 調查時期や調查範囲の不一致, あるいは 低いサンプル率などを原因とした不整合が生じている場 合が少なくない，楊ら ${ }^{13)}$ が，観測リンク交通量と利用者 均衡状態が不整合な場合には, 解が求まらないことを解 析的に明らかにしているように，入力データ間や仮定す る経路選択規範に不整合が生じる場合には，経路交通量 の推定值は得ることができない．

本研究では, プローブカーから得られる経路情報のデ 
一夕と車両感知器から得られる観測リンク交通量を用い て経路交通量を推定する数理モデルを提案する. 提案モ デルは，リンク交通量を確定的制約条件とするのではな $<$, 目的関数に組み込む. この考え方はWillumsen ${ }^{2)}$, 小 根山ら ${ }^{14)}$ の既往研究と基本的に同一であり, 観測誤差や 入力データ間に不整合が生じている場合でも, 経路交通 量の推定值を求めることが可能である. しかしながら, 得られた経路交通量の推定精度は入力データの信頼性に 依存するため, 信頼性が低い入力データのもとでは, 経 路交通量の推定精度は低くなる. そこで本研究では, 事 前OD交通量, 経路選択率, 観測リンク交通量などの入力 データ間に不整合が生じている場合においても経路交通 量を精度良く推定できるように，信頼性の高い観測值を 用いて不整合が生じている入力データ自体を修正する手 法を提案する. これにより, 既往研究を経路交通量の推 定モデルに適用した場合よりも経路交通量の精度向上が 期待される.

はじめに, モデルの基本部分を展開した後, 各種の観 測誤差が経路交通量の推定值に及ぼす影響を分析する.

続いて，信頼度の高、観測值に基づいて，入力データを 修正しながら，経路交通量の精度を向上させる手法につ いて説明し，提案手法を用いた適用計算結果について報 告する.

\section{2. 経路交通量推定モデルの定式化}

本研究では, プローブカー情報と車両感知器のデータ に基づいて経路交通量を推定するモデルを，同時生起確 率最大化による方法で定式化する.このモデルでは, 先 験確率を事前に与える必要があるが，観測值を確定的制 約条件として扱わなくても良いことから，観測值に誤差 が含まれている場合や，観測值間および入力データとの 間に不整合が生じている場合にも経路交通量の推定が可 能である.

経路交通量の推定モデルとして, 総交通量を不変とす る総交通量べースモデルと, $\mathrm{OD}$ 交通量を不変とする $\mathrm{OD}$ 交通量ベースモデルの 2 種類を定式化する. 総交通量べ 一スモデルでは, 先験確率で与えられる OD パターンの 構造が観測值に従って変化することが許されるが，OD 交通量ベースモデルでは，OD パターンおよび OD 交通 量の変化は許されない点が異なる．ただし，それぞれの モデルにおいて, 総交通量および $\mathrm{OD}$ 交通量を変動させ ることができる場合には，OD 交通量ベースモデルの方 が直接的に OD パターンおよび OD 交通量を変化させる ことが容易となる.

両モデルにおいて用いるプローブカー情報は，OD ペ アごとに集計され, OD 間の経路利用率の算出に利用可 能であると仮定する.

\section{（1）総交通量ベースモデル(モデル1)}

総交通量を不変とするモデルは，与えられた総交通量 のもとで, OD交通量に関する同時生起確率, 経路交通量 に関する同時生起確率およびリンク交通量に関する同時 生起確率のそれぞれを最大化にする問題として, 以下の 数理最適化問題として定式化される.ただし, OD交通量, 経路交通量，リンク交通量はそれぞれ互いに独立である と仮定する.

$$
\begin{aligned}
\max & {\left[\frac{\hat{T} !}{\prod_{i} \prod_{j} q_{i j} !} \prod_{i} \prod_{j}\left(\hat{b}_{i j}\right)^{q^{i}}\right] } \\
& \times\left[\prod_{i} \prod_{j} \frac{q_{i j} !}{\prod_{k} h_{i j k} !} \prod_{k}\left(\hat{p}_{i j k}\right)^{h_{j k}}\right] \times\left[\frac{\hat{V} !}{\prod_{l} v_{l} !} \prod_{l}\left(\hat{g}_{l}\right)^{v_{l}}\right]
\end{aligned}
$$

subject to

$$
\begin{aligned}
\hat{T} & =\sum_{i} \sum_{j} q_{i j} \\
v_{l} & =\sum_{i} \sum_{j} \sum_{k} \delta_{i j k}^{l} h_{i j k} \\
q_{i j} & =\sum_{k} h_{i j k} \\
\hat{V} & =\sum_{l \in I} v_{l}
\end{aligned}
$$

ここで, 記号 は与件であることを表し, 各変数の意 味は以下のようである.

$\hat{T}$ : 総交通量

$q_{i j} \quad:$ ゾーン $i-j$ 間の $\mathrm{OD}$ 交通量

$\hat{b}_{i j} \quad:$ ゾーン $i-j$ 間の $\mathrm{OD}$ 比率

$\hat{V} \quad$ : 観測リンク交通量の総和

$v_{l} \quad$ : リンクlのリンク交通量

$\hat{g}_{l} \quad$ : リンクlの観測リンク比率

$h_{i j k} \quad:$ ゾーン $i-j$ 間の第 $k$ 経路の交通量

$\hat{p}_{i j k} \quad:$ :゙ーン $i-j$ 閒の第 $k$ 経路の経路利用率

$\delta_{i j k}^{l} \quad:$ ゾーン $i-j$ 間の第 $k$ 経路がリンク $l$ を通る時 1 , その他を 0 とするダミー変数

$L \quad$ : 観測リンク交通量の集合

$\mathrm{OD}$ 比率, リンク比率は, 与件の事前 $\mathrm{OD}$, 観測リンク 交通量を用いて以下のように算出される.

$$
\begin{aligned}
& \hat{b}_{i j}=\frac{\hat{q}_{i j}}{\sum_{i} \sum_{j} \hat{q}_{i j}} \\
& \hat{g}_{l}=\frac{\hat{v}_{l}}{\sum_{l} \hat{v}_{l}}
\end{aligned}
$$

目的関数の対数を取り, スターリングの公式を用いて, その目的関数を変形したうえで, 制約条件にラグランジ エ乗数を導入する.式(2a)に対するラグランジェ乗数を $\eta$, 式(2b)に対するラグランジェ乗数を $\lambda$, 式(2d)に対する ラグランジェ乗数 $v$ を導入した. なお，式(2c)に対する 
ラグランジェ乗数は消去されたのち,式(5)が導出される.

一次の必要条件から以下の式が導かれる.

$$
\begin{aligned}
& \begin{array}{l}
h_{i j k}=\hat{p}_{i j k} \hat{b}_{i j} e^{\sum_{l} \lambda_{l} \delta_{i k}} e^{\eta} \\
v_{l}=\hat{g}_{l} e^{v-\lambda_{l}} \\
\sum_{i} \sum_{j} \sum_{k} \delta_{i j k}^{l} \hat{p}_{i j k} \hat{b}_{i j} e^{\sum_{n+1}^{\lambda_{n} b_{j k}^{n}} e^{n}}
\end{array} \\
& \eta=\log \frac{\hat{T}}{\sum_{i} \sum_{j} \sum_{k} \hat{p}_{i j k} \hat{b}_{i j} e^{\sum_{l}^{\lambda_{l} \delta_{i j k}^{l}}}} \\
& v=\log \frac{\hat{V}}{\sum_{l} \hat{g}_{l} e^{-\lambda_{l}}}
\end{aligned}
$$

経路交通量の推定値は, 式(7)，(8)，(9)を収束条件を満 たすまで繰り返し計算したのち, 得られたそれぞれの值 を式(5)に代入することにより求められる. 同様に, 式(6) からリンク交通量の推定值が求められる.

\section{（2）OD交通量ベースモデル(モデル2)}

$\mathrm{OD}$ 交通量を不変とするモデルは，与えられたOD交通 量のもとで，経路交通量に関する同時生起確率およびリ ンク交通量に関する同時生起確率のそれぞれを最大化に する問題として, 以下の数理最適化問題として定式化さ れる.ただし, 経路交通量, リンク交通量はそれぞれ互 いに独立していると仮定する.

$$
\begin{aligned}
& \max \left[\prod_{i} \prod_{j} \frac{\hat{q}_{i j} !}{\prod_{k} h_{i j k} !} \prod_{k}\left(\hat{p}_{i j k}\right)^{h_{j k}}\right] \cdot\left[\frac{\hat{V} !}{\prod_{l} v_{l} !} \prod_{l}\left(\hat{g}_{l}\right)^{v_{i}}\right] \\
& \text { subject to } \\
& \begin{aligned}
\hat{q}_{i j} & =\sum_{k} h_{i j k} \\
v_{l} & =\sum_{i} \sum_{j} \sum_{k} \delta_{i j k}^{l} h_{i j k} \\
\hat{V} & =\sum_{l \in l .} v_{l}
\end{aligned}
\end{aligned}
$$

目的関数の対数を取り，スターリングの公式を用いる ことにより目的関数を変形したうえで, 式(11a)の制約条 件に対するラグランジェ乗数を $\mu_{i j}$, 式(11b)の制約条件 に対するラグランジェ乗数を $\lambda_{l}$, 式(11c)の制約条件に対 するラグランジェ乗数を $v$ とし, 一次の必要条件から以 下の式が導かれる.

$$
\begin{aligned}
& h_{i j k}=\hat{p}_{i j k} e^{\sum_{1} \lambda_{i} \delta_{j k}} e^{u_{i j}} \quad \forall i j, \forall k \\
& v_{l}=\hat{g}_{l} e^{\nu-\lambda_{l}} \\
& \lambda_{l}=\frac{1}{2} \log \frac{\hat{g}_{l} e^{\nu}}{\sum_{i} \sum_{j} \sum_{k} \delta_{i j k}^{\prime} \hat{p}_{i j k} e^{\sum_{n=1} \lambda_{n} \delta_{i j k}^{n}} e^{u_{i l}}}
\end{aligned}
$$

上記に示した，経路交通量推定モデルを適用するうえ で, 総交通量, 事前 OD 交通量, プローブデータから得 られる経路利用率, 観測リンク交通量などが入力データ として必要である.しかし，これらのデータ間には，観 測精度, 調査範囲, 調査時点の不一致などの不整合によ る誤差が生じている場合も少なくない. そこで, 本研究 ではどの入力データの誤差が経路交通量の推定值に影響 を与えるかを把握するため，2 種類の経路交通量推定モ デルをテストネットワークに適用し，モデルによる推定 値の差異, 観測值に含まれる䛊差の影響などを分析する.

\section{（1）検証データの作成}

図一1に，ノード数 24, リンク数 $76, \mathrm{OD}$ ペア数 552 のテストネットワークを示す. OD 交通量は, 一様乱数 を用いて值を設定し，最小値は 570 台，最大值は 41939 台となった. リンクコスト関数には BPR 関数を利用し, 利用者均衡配分を行った. 配分結果から得られたリンク 交通量を観測リンク交通量とし，経路交通量は，松本ら ${ }^{15)}$ のモデルを用いて，観測リンク交通量に一致するよう に求めた. なお, 観測リンク交通量の最小値は41122 台, 最大値は227613 台となった。 
OD 間の個々のトリップを一定の割合でランダムにサ ンプリングしたものをプローブカーと見なし，そのサン プリング率をプローブカーの混入率とした. サンプリン グ方法は，OD ペアごとにサンプリングする方法と，ネ ットワーク全体からサンプリングする方法の 2 種類が考 えられる. 本研究では, 前者の方法でサンプリングを行 う。なお，同一の経路交通量の推定精度を得るには, OD ペアごとのサンプリングよりも，ネットワーク全体から のサンプリングの方が，高いサンプリング率を必要とす る ${ }^{16)}$. プローブカーの混入率は, 1\%から 100\%までの間 で複数設定した. プローブカーが走行する状況も複数作 り出すため, サンプリングはそれぞれの混入率で 10 回ず つ行い，モデルの適用計算もそれぞれのサンプリングご とに 10 回ずっ行った. このプローブカーから，OD間の 経路利用率を算出した.

なお，適用計算をするにあたり，経路交通量推定值に 対して，欠測リンクの影響，観測リンク交通量や既存の OD 交通量に誤差がある場合の影響を把握する.

\section{（2）欠測リンクの影響}

観測するリンクがネットワーク上の全てではなく，一 部が欠測している場合において，提案モデルによる推定 值がどのような影響を受けるかを分析する. 欠測リンク 数が全76リンク中の 20 リンクと 30 リンの 2 つ場合を検 証する．ただし，経路上に一点も観測リンクが存在しな い場合，提案モデルでは，リンク交通量による経路交通 量の修正が不可能となる. また，プローブデータが欠測 している経路は経路交通量を求めることが不可能である. そこで, プローブデータが存在し, 経路上に少なくとも 一点の観測リンクが存在する経路のみを精度検証の対象 とする.

図一2はモデル1でのプローブ混入率と推定経路交通量 のRMS誤差の平均との関係を, 久測リンク数ごとに図示 したものである. 図ー3はモデル2でのプローブ混入率と 推定経路交通量のRMS誤差の平均との関係を, 久測リン ク数ごとに図示したものである. 図より，プローブ混入 率は経路交通量の推定精度に直接的に大きく影響してい ることがわかる．一方，両モデルとも欠測リンク数の影 響は非常に小さく，モデルの違いによる差異も小さいこ とがわかり，リンク観測值に誤差がない場合で，経路上 に1点以上のリンク観測值が存在する場合には, リンク欠 測による推定経路交通量に対する影響はほとんど無いと 言える.

\section{（3）観測リンク誤差の影響}

経路交通量の推定時点とリンク交通量の観測時点が異 なる場合, その時点の違いによる誤差が考えられる。 そ こで，観測リンク交通量が誤差を有する場合を作り出す
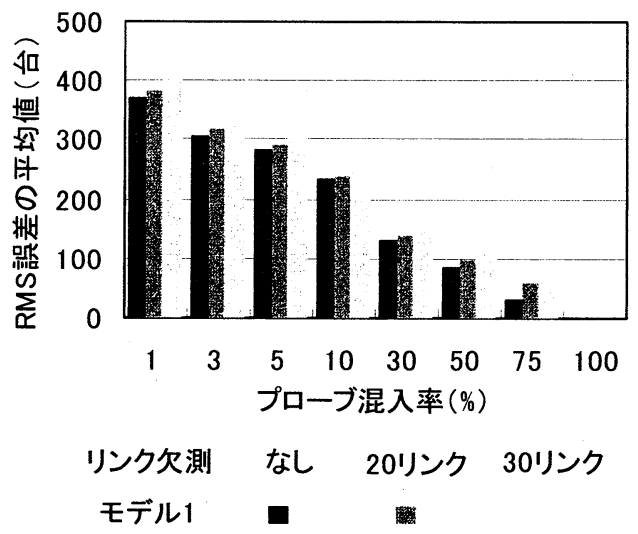

図-2 欠測リンク数ごとのプローブ混入率とRMS 誤差平 均との関係(モデル1)

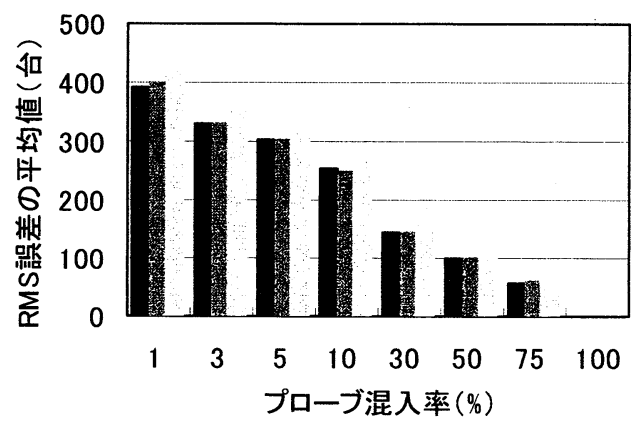

リンク欠測 なし 20リンク 30リンク

モデル2

図-3 欠測リンク数ごとのプローブ混入率とRMS誤差平 均との関係(モデル 2)

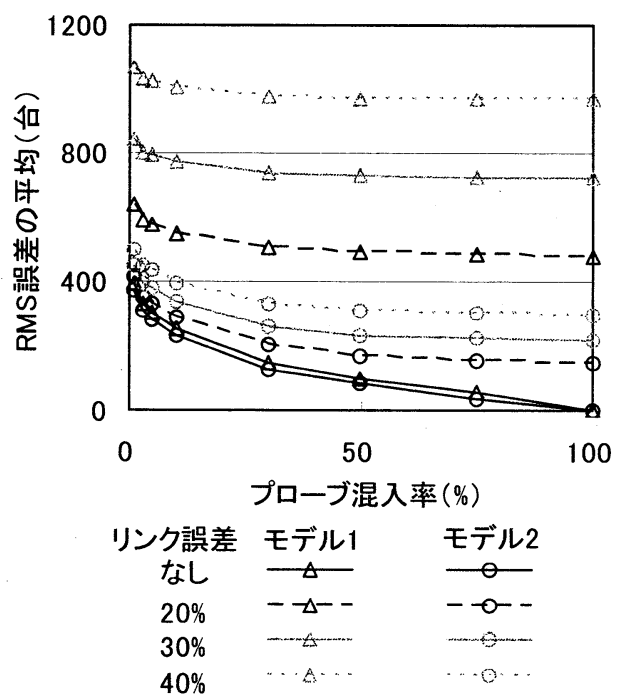

図ー4 観測リンク誤差ごとのプローブ混入率とRMS 誤差 の平均との関係 
ため, 観測リンク交通量の值から $\pm 20 \%, \pm 30 \%, \pm 40 \%$ の範囲で，一様乱数を用いて誤差を与えた.

図一4は, プローブ混入率と推定経路交通量RMS誤差 の平均との関係を, 観測リンク誤差の大きさごとに示し ている. 図より, 観測リンクの誤差が大きいほど, プロ 一ブの混入率の差異による影響が小さくなることがわか る. モデルに関しては, モデル2に比べるとモデル1の方 が観測リンクの誤差の影響を大きく受けることがわかる が,これは, モデル2ではOD交通量を不変にしているが, モデル1では観測值に応じてOD交通量も変化するという モデルの特性によると考えられる.

両モデルにおいて, プローブ混入率が高い場合におい ても推定誤差が生じているのは, 観測交通量に含まれる 誤差のため,データ間に不整合が生じていることによる. しかしながら，このようなデータ間に不整合が生じてい るような場合においても, 提案モデルでは経路交通量の 推定が可能であることがわかる.

\section{（4）事前OD交通量からの変化の影響}

提案する両モデルにおいては, 事前OD交通量あるいは それから得られる事前OD比率が与件であるが, この事前 $\mathrm{OD}$ 交通量から推定時点でのOD交通量に変化が存在する 場合を考える. 事前OD交通量としては, 道路交通センサ スやPT調査など過去に調査されたOD交通量データを用 いることが多いが, 調査データはサンプルに基づくもの であり, 小さなOD交通量の変化までは表現できない.ま た, 調査データは過去のものであり, 推定時点ではOD 交通量が変化している場合なども考えられ, 推定時 $\mathrm{OD}$ 交通量が調查時のOD交通量と比較して変化している場合 に, 推定值がどのような影響があるか検討しておく必要 がある.

OD交通量に, 観測リンク交通量が誤差を有する場合と 同様に， $\pm 20 \% ， \pm 30 \% ， \pm 40 \%$ の範用で，一様乱数を 用いて変化を与えた. 図一5はOD交通量に変化を与えた 場合における経路交通量のRMS誤差の平均を示している.

図より, OD交通量の変化が大きいほど, 曲線の傾きが ゆるやかになり，プローブ混入率の差異による影響が小 さくなることがわかる. モデルに関しては, モデルいの方 がモデル2に比べて, 全体的にRMS誤差の平均值が小さ いことがわかる.これは，モデルではOD交通量が観測 值に基づいて変化できるのに対して，モデル2では事前 OD交通量の值に固定されてしまうことによる.

両モデルにおいて, プローブ混入率が高い場合におい ても, 経路交通量の推定誤差が大きくなる場合もあると いう結果になった.これも, ODパターンが変化している ため, 事前OD交通量と推定時点での観測交通量の間に整 合がとれていないことによる.

図一6に，推定経路交通量の一例として，OD交通量の

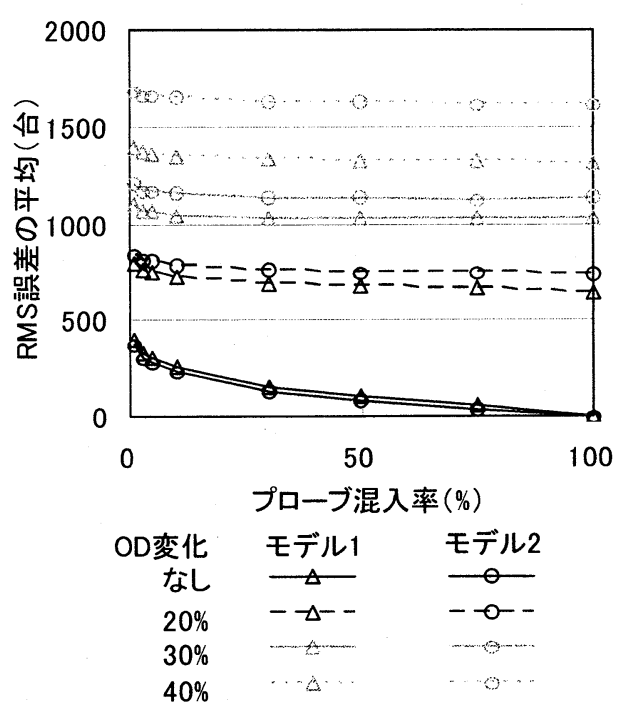

図-5 OD変化ごとのプローブ混入率とRMS 誤差の平均 との関係

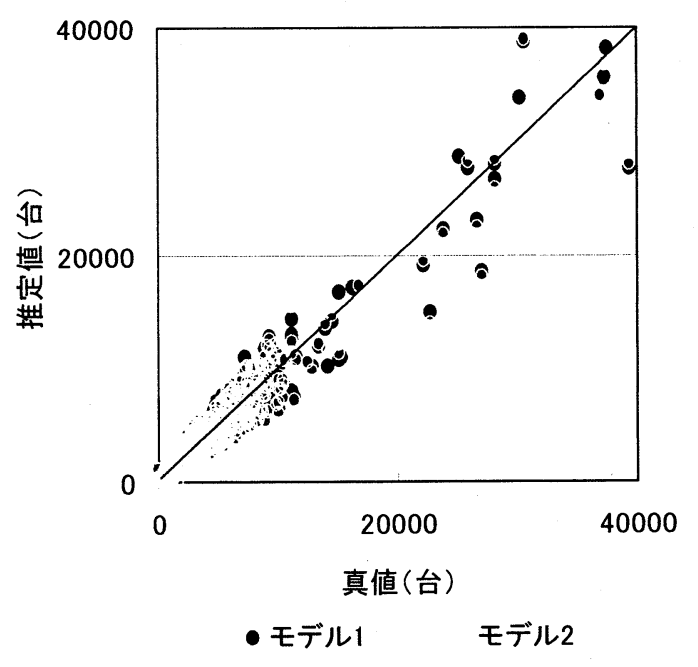

\section{図一6 プローブ混入率 75\%経路交通量の推定結果}

変化 $\pm 40 \%$, プローブ混入率 $75 \%$ における推定值と真值 の散布図を示寸. 図より, 両モデルとも45度線周辺に 点がプロットされ，良好な推定結果であることがわかる が, モデル2の方がモデル1に比べて, 特にOD交通量の值 が小さな場合においてばらつきが大きいこともわかる. なお, 相関係数はモデル1が0.94, モデル2が0.91であった.

\section{（5）観測リンク誤差とOD交通量変化の影響}

ここまでは, リンク交通量の観測誤差の影響とOD交通 量の変化の影響を別々に検討したが，ここでは，リンク 交通量に誤差が含まれ, かつ, OD交通量が変化した場合 
を考える.

図一7は,リンク交通量に観測誤差がありOD交通量が 変化したときの, 経路交通量のRMS誤差の平均を示す. 図より，これまでの結果と同様，リンク交通量誤差およ びOD交通量変化が大きいほど, プローブの混入率の差異 による影響が小さくなることがわかる.リンクあるいは OD交通量のみが差を有していたときに比べると,両モデ ルの差異は小さくなっている. また, モデル2では, OD 交通量だけに誤差が存在する場合より，推定誤差が減少 している.

この原因を検証するために，図一8にリンク誤差やOD 交通量の変化とRMS誤差の平均との関係として, 観測誤 差および変化が士40\%の場合を示す，図より，経路交通 量の推定誤差は, 観測リンク誤差のみ存在する場合は, プローブ混入率が高くなるに従って，推定誤差は小さく なっているが, OD変化がある場合にはその変化が大きく ないことがわかる.これは, プローブ混入率が高いほど, 経路選択率が高い精度で与えられ，その結果，各種観測 值との間の不整合が大きくなることによるものと考えら れる.

差の種類に着目すると, リンク交通量の観測誤差より も, $\mathrm{OD}$ 交通量の変化による経路交通量の推定誤差の方が 大きいことがわかる. しかしながら, OD交通量の変化よ りも, OD交通量の変化とリンク交通量の観測誤差が同時 にある場合の方が，経路交通量の推定誤差が小さくなっ ていることが見て取れる.これは, リンク交通量の観測 誤差がOD交通量の変化を吸収していることによるもので あると考えられる.ただし，本研究では観測リンク交通 量の誤差, OD交通量の変化をそれぞれ独立な一様乱数を 用いて発生させたため, OD交通量のパターンとリンク交 通量のパターンによっては両者の影響が打ち消された結 果とも考えられる.

\section{4. 推定誤差に基づく経路交通量の修正手法}

これまでの分析結果から，推定時点の OD 交通量が事 前 $\mathrm{OD}$ 交通量から変化している場合には, 経路交通量の 推定精度が大きく低下することが明らかとなった.さら に, プローブの混入率が低い場合でも, 経路交通量の推 定精度が低下寸ることが明らかとなった。一方, 観測リ ンク交通量の誤差の影響は，OD 交通量の変化による影 響よりも小さいことがわかった.

事前 OD 交通量と観測リンク交通量を入手データとし て比較した場合, 観測リンク交通量の方が入手は容易で あり，また，観測も容易であることから情報の信頼性も 高い. そこで本研究では, 入力データとして入手が容易 で信頼性の高いリンク交通量を用いて, 他の入力データ 自体を修正する手法を提案し, 経路交通量の精度の向上

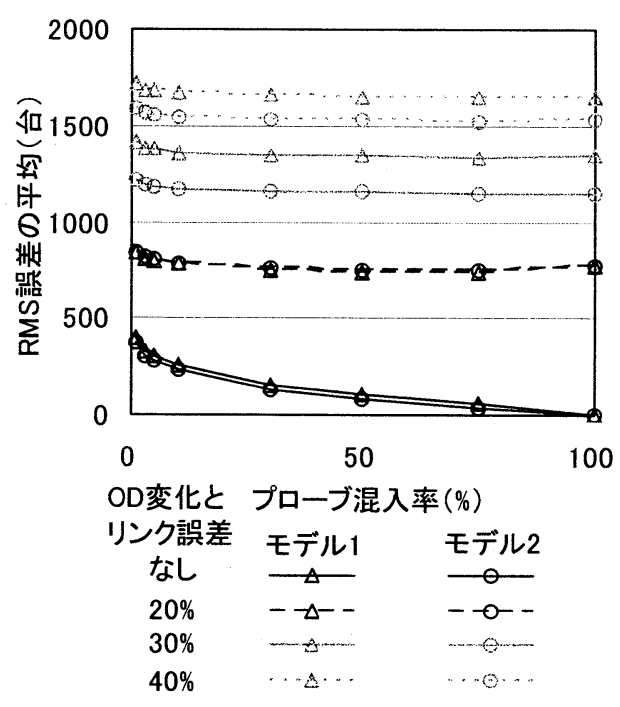

図ー7 リンク誤差と OD 変化ごとのプローブ混入率と $\mathrm{RMS}$ 誤差の平均との関係



圆リンク誤差

口OD変化

口OD変化とリンク誤差

図-8 各種観測誤差とプローブ混入率とRMS 誤差の平均 との関係

を図る. 入力データとしては総交通量または事前 OD 交 通量, プローブデータから得られる経路利用率, 観測リ ンク交通量の 3 種類がある. 基本的な考え方は, 2 つの 入力データは信頼性が高いデータであると仮定し, 残り 1 つは信頼性が低い入力データである時, 信頼性が高い 2 つの入力データを用いて, 信頼性の低い入力データ自体 を修正するというものである.これらの3 種類の入力デ 一タの修正パターンを表一1に示す.

まず，信頼性が高、観測リンク交通量とプローブデー タから得られる経路利用率が得られ, 総交通量や事前 $\mathrm{OD}$ 交通量の信頼性が低い場合, 経路交通量の推定結果に影 響を及ぼす総交通量および事前 OD 交通量を修正する手 法を提案する. 事前 OD 交通量の修正手法に関しては, 2 種類の方法で定式化する. さらに，信頼性が高い観測リ 
ンク交通量と事前 OD 交通量が得られ，プローブデータ から得られる経路利用率の信頼性が低い場合を仮定し， 経路利用率を修正する手法も提案する.

\section{（1）推定リンク誤差に基づく総交通量修正手法}

総交通量ベースモデルでは, 総交通量を変数とすると 多くの場合は劣決定問題となり解が得られないが, 総交 通量を不変とすると経路交通量と共に, リンク交通量の 推定值も得られる. しかしながらこの推定されたリンク 交通量と観測されたリンク交通量は必ずしも一致しない. これは, 総交通量ベースモデルでは総交通量を不変とし ており, 信頼性の低い総交通量の入力データであれば, リンク交通量の推定誤差も大きくなることによる. そこ で,ここでは不変としてきた総交通量を変数とみなし, 以下に示寸総交通量の関数である推定リンク交通量と観 測リンク交通量の残差二乗和が，最小となるような総交 通量を, 総交通量の修正值とする.

$$
\min \sum_{l}\left(v_{l}(T)-\hat{v}_{l}\right)^{2}
$$

ここで, リンク交通量は総交通量の関数として, 以下 のように表される.

$$
v_{l}(T)=\sum_{i} \sum_{j} \sum_{k} \delta_{i j k}^{l} h_{i j k}(T)
$$

上式に式(5)，(8)を代入し，式(18)を(17)の目的関数に 代入し, 総交通量で偏微分寸ると以下の式が導かれ, 総 交通量の修正值を得る.

$$
T=\sum_{l} \frac{\hat{v}_{l}}{\sum_{i} \sum_{j} \sum_{k} \frac{\delta_{i j k}^{l} \hat{p}_{i j k} \hat{b}_{i j} e^{\sum_{i}^{\lambda_{i j k}^{l} \delta_{i k}^{l}}}}{\sum_{i} \sum_{j} \sum_{k} \hat{p}_{i j k} \hat{b}_{i j} e^{\sum_{l}} \lambda_{j, k}^{l} \delta_{i k}^{l}}}
$$

この Tを修正総交通量とすればよいことになり, 経路 交通量を総交通量ベースモデルの入力データとして与え, 経路交通量を再度, 推定し直すことにより, リンク誤差 が小さな経路交通量の推定值が得られることになる.

\section{（2）残差二乗和最小化によるOD 交通量修正手法 (残差手法)}

OD 交通量ベースモデルでは, 事前 OD 交通量を不変 として扱い, 経路交通量の推定時点における OD 交通量 が事前 OD 交通量と大きく変化がない場合には，高い精 度で経路交通量の推定值が得られる. 一方, 事前 $\mathrm{OD}$ 交 通量と推定時点のOD交通量との間に差がある場合には, 経路交通量の推定精度は大きく低下寸る.しかしながら， 事前 $\mathrm{OD}$ 交通量を変数とすると, 多くの場合は劣決定問 題となり解が得られない.

そこで，観測リンク交通量の情報を用いて，事前 OD 交通量を修正する千法を提案する. OD 交通量べースーて

\begin{tabular}{|c|c|c|c|}
\hline パターン & \multicolumn{2}{|c|}{$\begin{array}{c}\text { 信頼度が高く与件の } \\
\text { 入カデータ }\end{array}$} & $\begin{array}{c}\text { 信頼性が低<修正 } \\
\text { する入力データ }\end{array}$ \\
\hline 1 & \multirow{3}{*}{$\begin{array}{c}\text { 観測 } \\
\text { リンク } \\
\text { 交通量 }\end{array}$} & 経路利用率 & 総交通量 \\
\hline 2 & & 経路利用率 & 事前 OD 交通量 \\
\hline 3 & & 事前OD交通量 & 経路利用率 \\
\hline
\end{tabular}
デルにより推定されるリンク交通量は, 事前 OD 交通量
表-1 入力データの修正パターン

の関数と見なすことができ, 総交通量ベースモデルと同 様に推定リンク交通量と観測リンク交通量の残差二乗和 を最小化する問題が定式化できる. ただし，観測リンク 交通量の情報のみでは問題が劣決定となり, 事前 OD 交 通量を一意に修正することができない，そこで，推定さ れた経路交通量から求まる推定OD交通量を固定值とし, それと事前 OD 交通量の残差二乗和項を付加した以下の モデルを定式化する.

$$
\min \sum_{l}\left(v_{l}\left(q_{i j}\right)-\hat{v}_{l}\right)^{2}+\sum_{i} \sum_{j}\left(q_{i j}-\sum_{k} h_{i j k}\right)^{2}
$$

この目的関数を事前 $\mathrm{OD}$ 交通量で偏微分すると以下の ようになる.

$\frac{\partial E}{\partial q_{i j}}=2 \sum_{l}\left(v_{l}\left(q_{i j}\right)-\hat{v}_{l}\right) \frac{\partial v_{l}\left(q_{i j}\right)}{\partial q_{i j}}+2\left(q_{i j}-\sum_{k} h_{i j k}\right) \quad \forall i j$

ここで，リンク交通量は事前OD交通量の関数として, 以下のように表される.

$$
v_{l}=\sum_{i} \sum_{j} \sum_{k} \delta_{i j k}^{\prime} \hat{p}_{i j k} q_{i j}
$$

上式よりリンク交通量の降下方向は, 式(22)を事前 OD 交通量で偏微分することにより, 次のようになる.

$$
\frac{\partial v_{l}\left(q_{i j}\right)}{\partial q_{i j}}=\sum_{k} \delta_{i j k}^{l} \hat{p}_{i j k} \quad \forall i j \quad \forall l \quad(23)
$$

これを式(21)に代入することにより，以下の事前 OD 交 通量の修正值を得る.

$q_{i j}=\frac{\sum_{k} h_{i j k}+\sum_{l}\left(\sum_{k} \delta_{i j k}^{l} \hat{p}_{i j k}\right)\left(\hat{v}_{l}-\sum_{n \neq i j}\left(\sum_{k} \delta_{n k}^{l} \hat{p}_{n k}\right) q_{n}\right)}{1+\left(\sum_{k} \delta_{i j k}^{l} \hat{p}_{i j k}\right)^{2}} \quad \forall i j$

修正された事前 OD 交通量を, 経路交通量の $\mathrm{OD}$ 交通 量ベースモデルの入力データとして与え, 経路交通量を 再度, 推定し直すことにより, リンク誤差が小さな経路 交通量の推定值が得られることになる.

\section{（3）リンク誤差分配によるOD 交通量修正手法 (分配手法)}

観測リンク交通量の情報を用いて, 事前 OD 交通量を 修正する方法をもう一つ提案する. 推定されたリンク交 通量と観測リンク交通量の誤差を用いて OD 交通量を修 正する方法は, 加藤ら ${ }^{177}$ にって提案されているが，本 研究では, 事前 $\mathrm{OD}$ 交通量の修正にプローブカーより得 
られる経路情報を用いるという点が異なる. また，この 経路情報の利用により，式(23)からわかるように，観測 リンク交通量と推定リンク交通量の残差二乗和の降下方 向となるので，収束が効率的になると考えられる.

はじめに，式(13)から算出されたリンク交通量と観測 リンク交通量の差分を, 式(23)の降下方向ベクトルの大 きさを用いて分配する.

$$
\varphi_{i j}^{l}=\left(\hat{v}_{l}-v_{l}\right) \times \frac{\sum_{k} \delta_{i j k}^{l} \hat{p}_{i j k}}{\sum_{i} \sum_{j} \sum_{k} \delta_{i j k}^{l} \hat{p}_{i j k}}
$$

次に，分配された修正量 $\varphi_{i j}^{l}$ を全リンク分足し合わせる ことによって, OD 交通量の修正量 $\Delta q_{i j}$ を算出する.

$$
\Delta q_{i j}=\sum_{l}\left(\varphi_{i j}^{l} \times \frac{\sum_{k} \delta_{i j k}^{l} \hat{p}_{i j k}}{\sum_{l} \sum_{k} \delta_{i j k}^{l} \hat{p}_{i j k}}\right)
$$

事前 $\mathrm{OD}$ 交通量の修正量 $\Delta q_{i j}$ を用いて, 修正事前 $\mathrm{OD}$ 交 通量 $q_{i j}^{\prime}$ を計算する.

$$
q_{i j}^{\prime}=q_{i j}+\Delta q_{i j}
$$

修正事前 OD 交通量の誤差が, 収束判定条件を満たさな い場合には, 再度, 事前 OD 交通量の修正計算を行う。 変数の更新として, 事前 OD 交通量とリンク交通量を再 度算出する。

$$
\begin{aligned}
& q_{i j}=q_{i j}^{\prime} \\
& v_{l}=\sum_{i} \sum_{j} \sum_{k} \delta_{i j k}^{\prime} \hat{p}_{i j k} q_{i j}
\end{aligned}
$$$$
\forall i j(28)
$$

本研究で提案した事前OD交通量の修正手法と経路交 通量の推定手法を同時に行う計算アルゴリズムを以下に 示寸.

Step0: 収束回数 $n_{1}=1, m=1$ とし, 制約条件(11)に対す るラグランジェ未定乗数 $\lambda_{l}^{(1)}, u_{i j}^{(1)}, v^{(1)}$ の初期值を 設定する.

Step1: 式(14)より， $\lambda_{l}^{\left(n_{1}\right)}$ を求める.

Step2: 式(15),(16)より， $\lambda_{l}^{\left(n_{1}\right)}$ を用いて $u_{i^{\prime}}^{\left(n_{1}\right)}, v^{\left(n_{1}\right)}$ を求め る.

Step3: $\lambda_{l}^{\left(n_{1}\right)}, u_{i j}^{\left(n_{1}\right)}, v^{\left(n_{1}\right)}$ の值が経路交通量推定モデルの 収束条件を満たしていれば Step4 に進む。 そう でなければ, $n_{1}=n_{1}+1$ として Step1 一戻る.

Step4: 式(12),(13)より， $h_{i j k}$ と $v_{l}$ の值を求める.

Step5: 収束回数 $n_{2}=1$ とし, 式(26)で $\Delta q_{i j}^{\left(n_{2}\right)}$ を計算し, 式(27)で $q_{i j}^{\left(n_{2}\right)}$ を求める.

Step6: 式(29)で $v_{l}^{\left(u_{2}\right)}$ を求める.

Step7: $q_{i j}^{\left(n_{2}\right)}$ の值がOD交通量修正モデルの収束条件を 満たしていれば Step8 に進む. そうでなければ $n_{2}=n_{2}+1$ として Step5 一戻る.

Step8: 両モデルの収束条件を満たしていれば終了。そ うでなければ $m=m+1$ として Stepl へ戻る.

\section{（4）経路利用率の修正手法}

プローブデータから算出される経路利用率の信頼性は, プローブカーの混入率に依存しているため, 混入率が低 ければ十分な経路利用率の信頼性を得ることはできない． この場合，信頼性の低いプローブデータに依存した経路 交通量が算出され, 観測リンク交通量と推定リンク交通 量の間に誤差が生じる．そこで，事前 OD 交通量と観測 リンク交通量は十分な信頼度を有している一方，十分な 混入率のプローブデータが入手できない場合，より精度 の高い経路交通量の推定值を得るため，観測リンク交通 量と推定リンク交通量が一致するように，プローブデー 夕により算出される経路利用率を修正する. 修正モデル としては，以下に示す算出された経路利用率と修正経路 利用率の残差二乗和最小化問題とした.

$$
\begin{array}{cll}
\min & \sum_{i} \sum_{j} \sum_{k}\left(\frac{p_{i j k}^{\prime}-\hat{p}_{i j k}}{\hat{p}_{i j k}}\right)^{2} & \\
\text { subject to } & \hat{v}_{l}=\sum_{i} \sum_{j} \sum_{k} \delta_{i j k}^{l} p_{i j k}^{\prime} \hat{q}_{i j} & \forall l \text { (31a) } \\
& \sum_{k} p_{i j k}^{\prime}=1.0 & \forall i j(31 \mathrm{~b})
\end{array}
$$

各変数の意味は以下のようである.

$p_{i j k}^{\prime} \quad:$ ゾーン $i-j$ 間第 $k$ 経路の修正経路利用率

$K \quad:$ :゙ーン $i-j$ 間の経路数

制約条件にラグランジェ乗数 $\lambda_{l}, \mu_{i j}$ を導入し, 目的 関数を解くことにより，一次の必要条件から以下の式が 導かれる。

$$
\begin{gathered}
p_{i j k}^{\prime}=\hat{p}_{i j k}-\hat{p}_{i j k}^{2} \frac{\sum_{l} \lambda_{l} \delta_{i j k}^{l} \hat{q}_{i j}+\mu_{i j}}{2} \quad \forall i j \quad \forall k \quad \text { (32) } \\
\lambda_{l}=\frac{\sum_{i} \sum_{j} \sum_{k} \delta_{j k k}^{l}\left(2 h_{i j k}-\hat{p}_{i j k}^{2} \hat{q}_{i j} \mu_{i j}-\hat{p}_{j k}^{2} \hat{q}_{i j} \sum_{n \neq l} \lambda_{n} \delta_{i j k}^{n} \hat{q}_{i j}\right)-2 \hat{v}_{l}}{\sum_{i} \sum_{j} \sum_{k} \delta_{i j k}^{l} \hat{q}_{i j}^{2} \hat{p}_{i j k}^{2}} \forall l \quad \text { (33) } \\
\mu_{i j}=\frac{2 \sum_{k} \hat{p}_{i j k}-\sum_{k} \hat{p}_{i j k}^{2} \sum_{l} \lambda_{l} \delta_{i j k}^{l} \hat{q}_{i j}-2.0}{\sum_{k} \hat{p}_{i j k}^{2}} \forall i j \quad \text { (34) }
\end{gathered}
$$

修正された経路利用率を，経路交通量の OD 交通量べ 一スモデルの入力データとして与え, 経路交通量を再度, 推定し直すことにより, 経路利用率の誤差が小さな経路 交通量の推定值が得られることになる。

\section{(5) 適用事例}

表一2 は, プローブ混入率 $75 \%, 100 \%$ の場合におおる 総交通量の修正前後での, 経路交通量の推定結果を示寸. 表より, 修正後では経路交通量の RMS 誤差が修正前よ り大きく減少しているのがわかる．また，OD 交通量の 変化に関係なく, 修正後の精度は等しくなっていること 
表-4 観測リンク交通量の推定結果

\begin{tabular}{|c|c|c|c|}
\hline $\mathrm{OD}$ 変化 & $40 \%$ & 修正前 & 修正後 \\
\hline リンク & RMS 誤差 & 6357.13 & 0.80 \\
\cline { 2 - 4 } 交通量 & 相関係数 & 0.98 & 1.00 \\
\hline
\end{tabular}

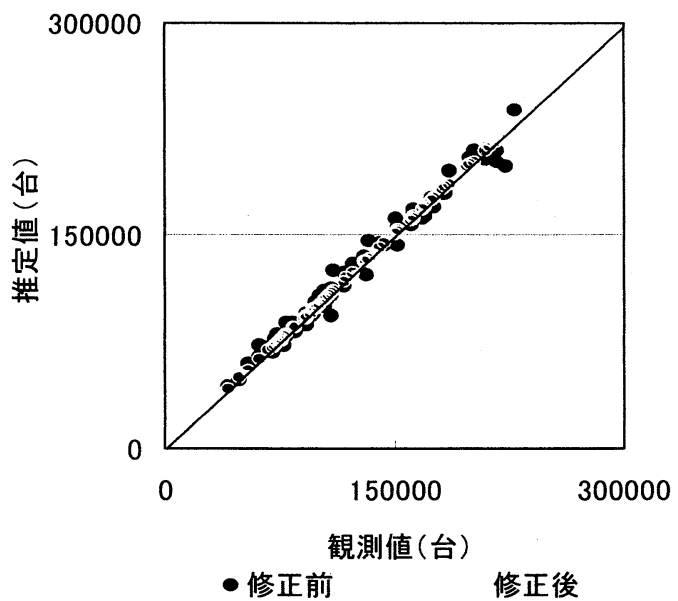

図ー10＼cjkstart観測リンク交通量の修正結果

がわかる.これはモデルの特性で，事前 $\mathrm{OD}$ 交通量が変 化しないことによるものと考えられる. プローブ混入率 で比較すると, プローブデータが多少の誤差を有してい ても, 経路交通量の推定精度は大きく変わらないことが わかる.

表一3 は, プローブ混入率 75\%, 100\%の場合における OD 交通量の修正前後での, 経路交通量の推定結果を示 す. 表より, 両モデルとも経路交通量の推定精度が向上 していることがわかる. モデルによる差異は, モデル 1 のほうがモデル2よりも若干精度が高いことがわかる. 次に，プローブ混入率で比較すると，プローブデータに 多少の誤差を与えても, 推定精度は変わらないことがわ かる.

図一9 は, OD 交通量の変化を $30 \%$ 与え，プローブ混 入率が $75 \%$ の場合の経路交通量の修正結果を示寸．図よ り，本修正手法では，定式化が比率を元とした修正とな っているため経路交通量が大きい経路ほど，修正量が大 きくなっていることがわかる．また，モデル1の方が修 正量が大きいこともわかる.

図一10 は, OD 交通量の変化を $40 \%$ 与えた場合のリン ク交通量の修正結果の一例を示寸。また，表一4 は OD 交通量の修正前後でのリンク交通量の RMS 誤差と相関 係数の関係を示している. これらより, リンク交通量は OD 交通量を修正した後で，推定経路交通量よりも大き く精度が向上し，ほほ観測リンク交通量と一致している ひがわかる。
表一2 総交通量の修正による経路交通量の推定結果

\begin{tabular}{|c|c|c|c|c|}
\hline \multirow{2}{*}{} & & \multicolumn{3}{|c|}{ 経路交通量 RMS 誤差 (台) } \\
\cline { 2 - 5 } & OD 変化 & $20 \%$ & $30 \%$ & $40 \%$ \\
\hline 混入率 & 修正前 & 19391.18 & 19150.01 & 19554.00 \\
\cline { 2 - 5 } $75 \%$ & 修正後 & 37.74 & 37.74 & 37.74 \\
\hline 混入率 & 修正前 & 19394.36 & 19153.16 & 19557.19 \\
\cline { 2 - 5 } $100 \%$ & 修正後 & 0.07 & 0.07 & 0.07 \\
\hline
\end{tabular}

表－3 OD 交通量の修正による経路交通量の推定結果

\begin{tabular}{|c|c|c|c|c|}
\hline \multirow{2}{*}{$\begin{array}{c}\text { 混入率 } \\
75 \%\end{array}$} & & \multicolumn{3}{|c|}{ 経路交通量 RMS 誤差（台） } \\
\hline & $\mathrm{OD}$ 変化 & $20 \%$ & $30 \%$ & $40 \%$ \\
\hline OD 修正 & 修正前 & 768.54 & 1196.96 & 1450.91 \\
\hline 残差手法 & \multirow{2}{*}{ 修正後 } & 686.32 & 1076.64 & 1342.53 \\
\hline 分配手法 & & 690.93 & 1093.49 & 1364.22 \\
\hline $100 \%$ & & & & \\
\hline $\mathrm{OD}$ 修正 & 修正前 & 768.03 & 1196.96 & 1450.18 \\
\hline 残差手法 & \multirow{2}{*}{ 修正後 } & 683.25 & 1076.64 & 1341.73 \\
\hline 分配手法 & & 687.10 & 1093.73 & 1366.08 \\
\hline
\end{tabular}

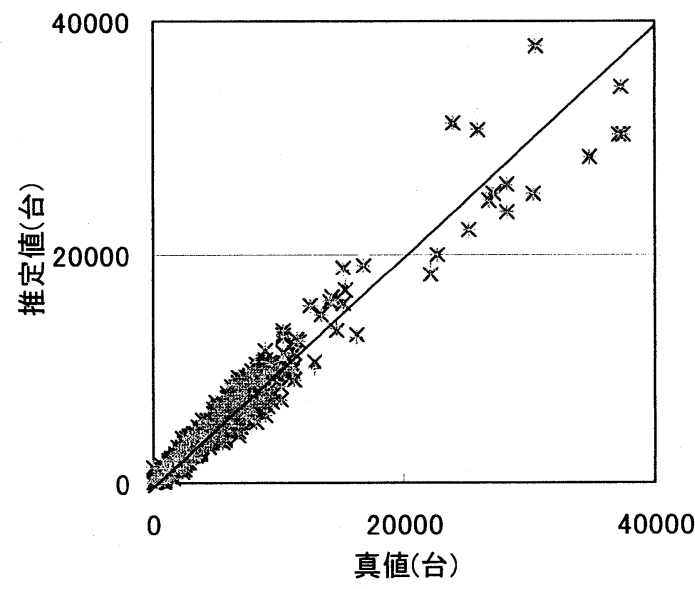

修正前 $\times$ 残差手法 焂正後配手法

\section{図-9 経路交通量の修正結果}

以上より，観測リンク交通量とプローブデータを用い て OD 交通量を修正する手法を 2 種類提案したが，両提 案モデルとも OD 交通量を修正することにより, 経路交 通量の推定精度を向上させることができることがわかっ た. 特に, 両モデルともプローブデータに多少の誤差が 存在する場合でも, 経路交通量の推定精度を向上させる ことが可能であることがわかった.

次に, 経路利用率の修正結果を見る. 表一5 は, プロ 一ブデータの修正モデルによる経路交通量の修正結果を 示寸. 表より, 経路利用率の修正後では, 経路交通量の RMS 誤差が減少しているのがわかる. 
図ー11 にプローブ混入率 10\%の場合における経路交 通量の修正結果の一例を示寸，ただし，OD ペアに経路 が 1 本しか存在しない経路は省いた．図より，修正前は 経路交通量にばらつきが見られるが，修正後経路交通量 が大きい経路ほど修正量が大きいことがわかる.

図一12に, プローブ混入率 10\%での経路利用率の修正 結果の一例を示す．ただし，先ほどと同様に ODペアに 経路が 1 本しか存在しない場合は省いた. 図より, プロ ーブデータの修正後は45度線付近にプロットされている のがわかる. なお，相関係数は，修正前が 0.97 , 修正後 は 0.98 となり若干だが向上した.

以上のことから，観測リンク交通量と事前 OD 交通量 に基づいて，経路利用率を修正した場合も，OD 交通量 修正モデルと同椂に, 経路交通量の推定精度が向上する ことがわかった．また，OD 交通量修正モデルと経路利 用率修正モデルの両モデルとも，経路交通量が大きい経 路ほどその推定精度が向上していることがわかった。

\section{6. おわりに}

本研究では, プローブカーと車両感知器のデー夕に基 づいて, 経路交通量を同時生起確率最大化による方法で 推定する手法を定式化した．はじめに，経路交通量の推 定モデルとして, 総交通量を不変とする総交通量ベース モデルと，OD 交通量を不変とする OD 交通量ベースモ デルの 2 種類を定式化した. そして, 観測リンク交通量, 事前 OD 交通量に誤差を含ませるなど幾つかの条件を設 定し, モデルによる推定値の差異, 観測值に含まれる誤 差の影響などを分析した。

続いて，入力デー夕に観測誤差がある場合に経路交通 量の推定精度を向上させるため, 観測リンク交通量とプ ローブデータを用いた総交通量修正手法および事前 OD 交通量修正手法を提案した. また，観測リンク交通量と OD 交通量を用いた経路利用率の修正手法を提案した.

以下，本研究で得られた主な知見をまとめる.

(1) 本研究で提案した総交通量べースモデルと，OD 交 通量ベースモデルでは，観測誤差が経路交通量の推 定精度に与える影響が異なることがわかった。観測 リンクの誤差の影響は, 総交通量ベースモデルの方 が大きく受け, OD 交通量の変化の影響は OD 交通 量べースモデルの方が大きく受けることがわかった.

(2) リンク欠測による推定経路交通量に対する影響はほ とんどないことがわかった。 ソ゚ローブU混入率が高 い場合において推定誤差が大きくなる原因として, 経路選択率と入力デー夕間の不整合が考えられた. さらに, OD 交通量の変化と観測リンク交通量の誤 差が同時に発生した場合, リンク誤差が OD 交通量 の変化を吸収してしまう場合があることが明らかと

\section{表-5 経路交通量の推定結果}

\begin{tabular}{|c|c|c|c|c|}
\hline & 混入率 & $1 \%$ & $3 \%$ & $5 \%$ \\
\hline \multirow{2}{*}{ 修正前 } & RMS 誤差 & 384.84 & 311.12 & 306.54 \\
\cline { 2 - 5 } & 相関係数 & 0.99 & 0.99 & 0.99 \\
\hline \multirow{2}{*}{ 修正後 } & RMS 誤差 & 253.82 & 179.44 & 182.26 \\
\cline { 2 - 5 } & 相関係数 & 0.99 & 0.99 & 0.99 \\
\hline & 混入率 & $10 \%$ & $50 \%$ & $75 \%$ \\
\hline \multirow{2}{*}{ 修正前 } & RMS 誤差 & 265.22 & 83.61 & 34.87 \\
\cline { 2 - 5 } & 相関係数 & 0.99 & 1.00 & 1.00 \\
\hline \multirow{2}{*}{ 修正後 } & RMS 誤差 & 179.74 & 51.36 & 20.5 \\
\cline { 2 - 5 } & 相関係数 & 0.99 & 1.00 & 1.00 \\
\hline
\end{tabular}

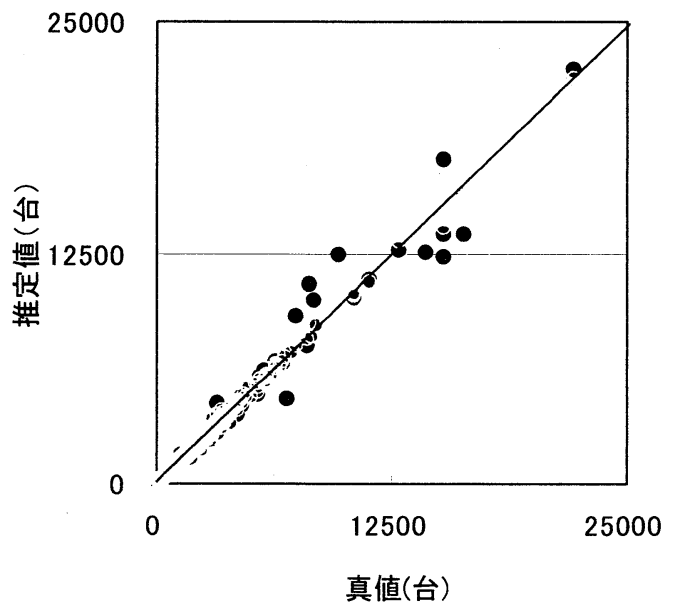

・修正前 修正後

図-11 経路交通量の修正結果

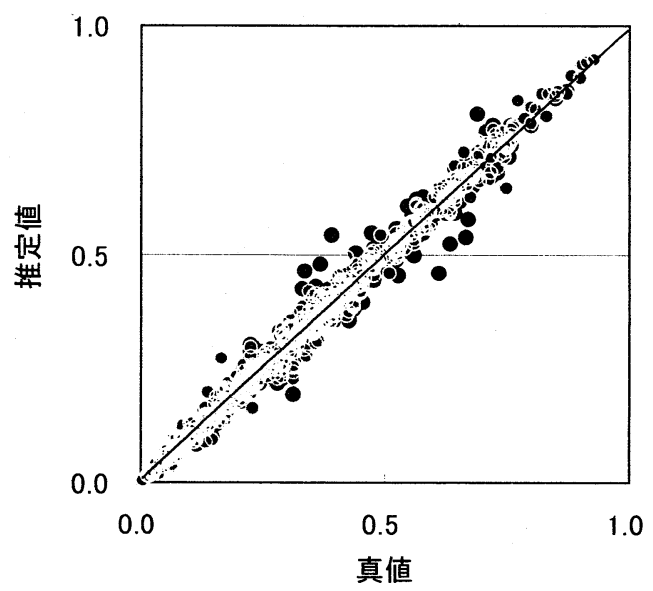

・修正前修正後

図-12 経路利用率の修正結果 
なった.

（3）プローブデータと観測リンク交通量を用いて総交通 量, 事前 OD 交通量を修正する手法を 2 種類提案し た. その結果, 総交通量および事前 OD 交通量を修 正できることがわかった．また，経路交通量の推定 精度は, 修正前と比較して向上することがわかった.

(4) 観測リンク交通量と OD 交通量を用いて経路利用率 を修正する手法を提案した. その結果, プローブの 混入率によらず，経路利用率が修正可能であること がわかった. また, 経路交通量の推定精度は, 修正 前と比較して向上することがわかった.

本研究では, OD交通量, 経路交通量, リンク交通量が 互いに独立と仮定したうえで, モデル構築を行っている. 今後の課題として，それらの交通量の従属関係が経路交 通量の推定精度に及ぼす影響を分析する必要がある.ま た, $\mathrm{OD}$ 交通量の変化と観測リンク交通量の誤差の様々な 発生パターンを計算し, リンク誤差がOD交通量の変化を 吸収するメカニズムの解明する必要がある. 本研究では プローブカーを高い混入率で設定し適用計算をしている 場合があるが，現実に即したプローブカーの混入状況を 想定したモデルの適用計算を進める必要がある.さらに, 本研究で提案した総交通量, 事前OD交通量および経路選 択率の修正モデルは，その解析的特性が明確になってい ない. したがって, 得られる解の特性やより効率的な解 法について今後さらなる研究を進める必要がある.

\section{参考文献}

1) Zuylen, H.. J. V. and Willumsen, L.G. : The most likely trip matrix estimated from traffic counts, Transportation Research 14B, 281-293, 1980.

2) Willumsen, L. G.. : Estimating time-dependent trip matrices from traffic count, Ninth International Symposium on Transportation and Traffic Theory, 397-411, 1984.

3）楊海, 朝倉康夫, 飯田恭敬, 佐佐木綱 : 交通混雑を考 慮した観測リンク交通量からのOD推計モデル，土木学 会論文集，No.440/ IV-16，pp.117-124，1992.

4）松本幸正, 藤田素弘, 松井寛 : 交通量観測値に基づく 動的OD交通量の再帰的推定に関する研究，土木学会論 文集, No.590/IV-394, pp.63-78, 1998.

5) Cheng, L., Iida, Y., Uno, Y and Wang, W. : Efficient Implementation of Bilevel Programming Model for Origin-Destination Estimation, Proceedings of Infrastructure Planning, Vol.28, p.4, CD-ROM,2003.

6) Bell, M. G. H., Shield, C. M., Busch F. and Kruse, G., (1997) A stochastic user equilibrium path flow estimator, Transportation Research 5C 197-210.

7) Matsumoto, Y., Matsui, H. Fujita, M. and Takahashi, M., (1999) Recursive estimation of path flows from traffic counts for real-time traffic control, 6th World Congress on
Intelligent Transport Systems, CD-ROM, \#381.

8) 北村清洲, 山本俊行, 吉井稔雄, 森川高行 : 交差点迁 回調査に基づくプローブデータの有用性の検討，交通 工学研究発表会論文報告集, No23, pp153-156, 2003.

9) 三輪富生, 多和田雄介, 山本俊行, 森川高行 : 蓄積デ 一夕による予測旅行時間の更新手法に関寸る研究，土 木学会年次学術講演会講演集, No59, CD-ROM, 2004.

10) 三輪富生, 倉内慎也, 森川高行 : 意思決定タイミング を内生化した動的な経路選択モデルの構築，土木計画 学研究・講演集, No30, CD-ROM, 2004.

11）小根山裕之・桑原雅夫 : プローブカーの経路情報を用 いた時間帯別 OD 交通量の推定, 第 57 回年次学術講演 概要集, pp813-814, 2002

12）三谷卓摩，羽藤英二：プローブ経路データを利用した 動的OD交通量の推定，第24回交通工学研究発表会論文 報告集, pp.289-292，2004

13）楊海, 佐佐木綱 : ネットワーク均衡に基づく観測リン ク交通量からのOD交通量推計法に関する検討, 土木計 画学研究・論文集, No.9, pp.29-36, 1991

14) 小根山裕之, 桑原雅夫 : 路側観測交通量からの時間OD 交通量の推定, 交通工学, Vol27, pp5-16, 1997.

15）松本幸正, 黒川卓司, 松井寛: 利用者均衡ンクク交通 量に一致する経路交通量推定手法の比較分析, 交通工 学研究発表会論文報告集, No23, pp165-168, 2003.

16）堀場庸介, 松本幸正, 松井寛, 黒川卓司: サンプリン グと観測誤差がプローブデータに基づく経路交通量推 定值に与える影響, 土木計画学研究・講演集, No30, CD-ROM, 2004.

17) 加藤義昭, 小川裕亮, 藤井聡, 菊池輝, 北村隆一: 交 通流シュミレータDEBNETsを利用したOD推定アルゴ リズムの開発, 土木計画学研究・講演集, No28, CD-ROM, 2003. 


\title{
プローブデータに基づく推定経路交通量への観測誤差の影響分析と推定経路交通量の更新手法*
}

\author{
堀場庸介** ・松本幸正 $* * *$ 松井寛 $* * * *$. 高橋政稔 $* * * * *$
}

本研究では, プローブデータと車両感知器のデータに基づく経路交通量の推定モデルを, 同時生起確率最大化 による方法とし，総交通量ベースモデルと，OD交通量ベースモデルの2種類を定式化した. そして，プローブ データ, 観測リンク交通量, 既存のOD交通量に誤差を含ませるなど幾つかの条件を設定し，2種類の提案モデ ルでの各種観測誤差の影響を把握した. さらに, 経路交通量の精度向上のため入力データ自体を修正する手法 として, 総交通量, OD交通量の誤差を修正する手法，プローブデータの誤差を修正する手法を提案し，簡単な ネットワークで提案モデルの適応性を検証した. その結果, 本研究で提案した修正手法により, 経路交通量の 推定精度は，観測誤差を修正する前と比較し向上させることができた.

\section{Influence of Measurement Errors of Input Data on Path Flow Estimations from Probe Vehicle Information and Modification of Estimated Path Flows*}

By Yosuke HORIBA** • Yukimasa MATSUMOTO*** • Hiroshi MATSUI**** • Masami TAKAHASHI

Total flow and O-D flow based models for estimating path flows using probe vehicle information and traffic counts are constructed as a mathematical programming in which probabilities of simultaneously occurrence are maximized. First, when input data of prior total flow and O-D flows; observed link flows, and a prior probability of each path flow have some errors and inconsistency, differences of two proposed models are analyzed. Secondly, modification methods of input data are proposed to update estimated path flows. The proposed models were applied to a simple network. As a result, link traffic counts and prior O-D flows and total flow had some errors and were inconsistent, the proposed models were able to yield estimations of path flows. Furthermore, it was clarified that accuracy of estimated path flows was improved by using the proposed modification methods. 